\title{
TESTES COLORIMÉTRICOS PELA METODOLOGIA LABEL-FREE PARA IDENTIFICAÇÃO DA PARACOCCIDIOIDOMICOSE
}

\author{
Olavo de Osti Comparato Filho' \\ Marcela Aparecida Cândido² \\ Guilherme Mosquim Lemes ${ }^{3}$ \\ Leandro José Raniero ${ }^{4}$
}

Resumo: Paracoccidioidomicose é uma doença que afeta principalmente os pulmões, podendo progredir por meio da disseminação para outros sistemas. A infecção é causada pelo Paracoccidioides brasiliensis, um fungo termodimórfico, que modifica sua forma de micélio para levedura a uma temperatura de $37^{\circ} \mathrm{C}$. $\mathrm{O}$ objetivo deste estudo foi identificar a presença do Paracoccidioides brasiliensis por meio de nanopartículas de Ouro, combinadas com o gene gp27, usando a metodologia Label-free. Inicialmente, AuNPs foram sintetizadas com caracterização do diâmetro em $22 \mathrm{~nm}+2 \mathrm{~nm}$ e uma banda de SPR centrada em $523 \mathrm{~nm}$. O DNA do fungo foi amplificado usando a região do gene gp27 utilizando os oligonucleotídeos CTGTTGTTTCCGTCCTTGCGC-F e AACTCTTGGCTTTGGTTGAAG-R. Os testes colorimétricos são compostos de oligonucleotídeos específicos, AuNPs e DNA teste. Os resultados mostraram mudança de coloração da solução coloidal na presença de DNA do fungo.

Palavras-chave: Gp27; Label-free; Nanopartículas de ouro; Paracoccidioides brasiliensis.

\footnotetext{
${ }^{1}$ Laboratório de Nanossensores, IP\&D/Universidade do Vale do Paraíba, Brasil. E-mail: ocfilho69@hotmail.com. 2 Laboratório de Nanossensores, IP\&D/Universidade do Vale do Paraíba, Brasil. E-mail: marcela.aparecida.candido@gmail.com.

${ }^{3}$ Laboratório de Nanossensores, IP\&D/Universidade do Vale do Paraíba, Brasil. E-mail: gui.lemes10@gmail.com.

${ }^{4}$ Laboratório de Nanossensores, IP\&D/Universidade do Vale do Paraíba, Brasil. E-mail: Iraniero@univap.br.
} 